\title{
Phenomenon of Microphase Heterogenization by Means of Endocrypt-Scattered Impurity of Rare and Noble Metals as a Result of Radiation by Accelerated Electrons of Bauxites
}

\author{
I. Razmyslov ${ }^{1(\bowtie)}$, O. Kotova ${ }^{1}$, V. Silaev ${ }^{1}$, and L. A. Gomze ${ }^{2}$ \\ ${ }^{1}$ Institute of Geology Komi SC UB RAS, Syktyvkar, Russia \\ razmyslov-i@mail.ru \\ ${ }^{2}$ University of Miskolc, Miskolc, Hungary
}

\begin{abstract}
During radiation-thermal transformation of Timan ferrous bauxites we discovered a previously unknown phenomenon of microphaseheterogenization, which can contribute to the extraction of many valuable impurities during processing of relatively poor quality bauxite raw.
\end{abstract}

Keywords: Bauxite $\cdot$ Radiation-thermal transformation •

Microphase heterogenization - Profitability of bauxite raw processing

\section{Introduction}

The problem of processing of aluminum ores is related to the fact that bauxite-forming minerals are characterized by similar values of density, dispersion and fine mutual intergrowths of individuals, non-recoverability of many valuable microelements. Therefore, the development and improvement of methods for the enrichment and processing of bauxite remains highly relevant (Borra et al. 2015; Borra et al. 2016; Davros et al. 2016). In terms of their iron index, the studied Timan bauxites are subdivided into three mineral types: hematite-boehmite, hematite-berthierine-boehmite, and berthierine-boehmite (Vakhrushev 2011, 2012; Vakhrushev et al. 2012). The results of our studies showed that in these bauxites in the state of endocrypt scattering there are a lot of valuable elements-impurities, which extraction by modern technologies is either time consuming or not yet possible. Our experiments on heating of bauxites in combination with their irradiation with high-energy electrons lead to a change in the phase composition of bauxites and, as a result, to the improvement of their technological properties (Rostovtsev 2010; Kotova et al. 2016).

\section{Methods and Approaches}

We carried out experiments with thermal (heating to 500 and $600{ }^{\circ} \mathrm{C}$ with quadruple exposure by $60 \mathrm{~min}$ ) and radiation-thermal (heating to $500-600{ }^{\circ} \mathrm{C}$ with double exposure by $20 \mathrm{~min}$ with irradiation by an electron beam with energy of $2.4 \mathrm{MeV}$ 
using ILU-6 industrial unit at the Institute of Nuclear Physics of the Siberian Branch of the Russian Academy of Sciences) modification of Timan iron bauxites.

\section{Results and Discussion}

Heating up to $500-600{ }^{\circ} \mathrm{C}$ with exposure to $60 \mathrm{~min}$ without irradiation led to almost complete dehydration of $\mathrm{Al}$ and $\mathrm{Fe}$ oxyhydroxides with the formation of $\gamma \mathrm{Al}_{2} \mathrm{O}_{3}$ (spinelide with a defective structure) and hematite with relatively small alteration of structure and magnetic properties of the rocks. The gross chemical composition of the annealed samples remained almost unaltered, and the content of trace elements increased markedly in\% to the original: $\mathrm{Cu}$ by $70-250 ; \mathrm{Zn}$ by $20-25 ; \mathrm{Cd}$ by $20-380 ; \mathrm{Zr}$ by $2-20$; Nb by $15-20$; Sc by $25-40$; Y by $35-70$; Ce by $25-60$; Nd by $1-10$. Obviously, the latter is conditioned bya significant thermal dehydration of the studied bauxites.

The radiation-thermal treatment of ferrous bauxites led not only to dehydration of the original minerals, but also to chemical disproportionation of the original substance, its radical magnetic restructuring resulted from the presence of strong magnetic phases (maghemite, magnetite) and the formation of valuable trace elements of many new minerals with individuals varying in shape from isometric to needle-like and in size from submicronic to $0.5 \mathrm{~mm}$ due to endocrypt scattered impurity. The newly formed phases include native metals ( $\mathrm{Au}, \mathrm{Pb}, \mathrm{Al}, \mathrm{Cu}, \mathrm{Zn}$ ); sulfides (pyrite, galena); oxides of $\mathrm{Sn}, \mathrm{Ta}, \mathrm{Nb}, \mathrm{Zr}$, lanthanides; silicates (zircon, kaolin); rare sulphates, etc. Thus, the heating, combined with irradiation with high-energy electrons, resulted not only in transformation of primary minerals in the ferrous bauxites, but also in microphase heterogenization with the formation of new minerals (Fig. 1). It can be assumed that this kind of transformation can contribute to extraction of many valuable impurities and increase the profitability of processing of relatively low-quality bauxite raw.
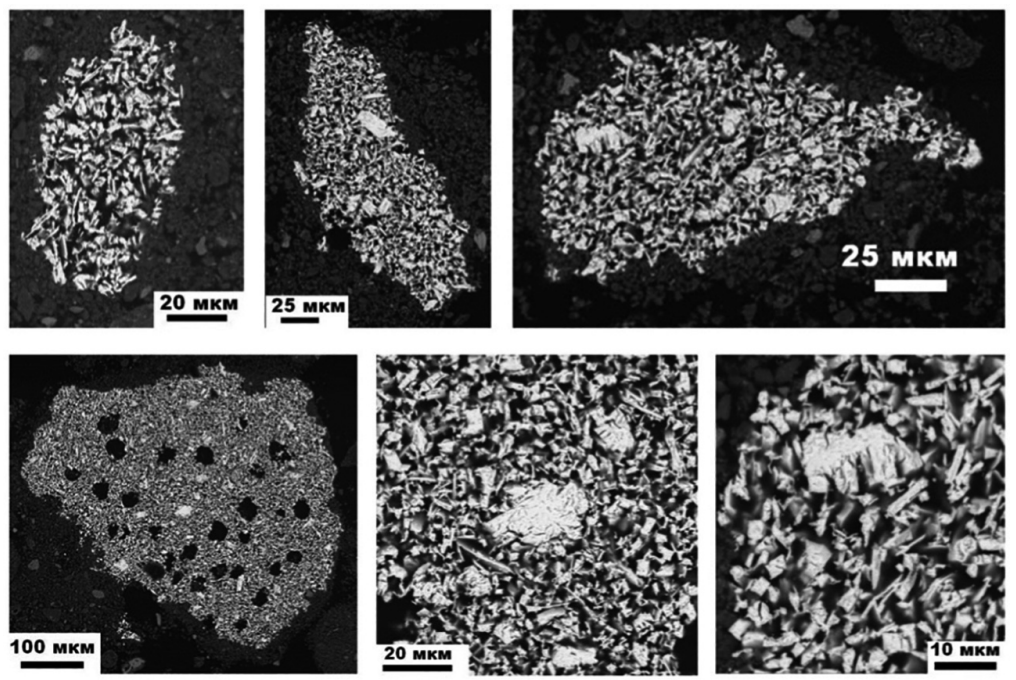

Fig. 1. Micro pocket segregations of Ce-Gd oxides in radiation-thermally modified Timan bauxites 
Acknowledgements. This research was supported by UB RAS project 15-18-5-44 and project AAAA-A19-119031390057-5 "The main directions of integrated assessment and effective use of geo-resources in the Timan-North Ural-Barents Sea region”.

\section{References}

Borra CR, Mermans J, Blanpain B, Pountikes YB, Gerven T (2016) Selective recovery of rare earths from bauxite residue by cjmbination of sulfation, roasting and leaching. Min Eng 92:151-159

Borra CR, Pontikes Y, Binnemans K, Gerven T (2015) Leaching of rare earts from bauxite residue (red mud). Min Eng 76:20-27

Davros P, Balomenos E, Panias D, Paspaliaris I (2016) Selective leaching 0f rare earth elements from bauxite residue (red mud). Hydrometallurgy 164:125-135

Kotova OB, Razmyslov IN, Rostovtsev VI, Silaev VI (2016) Radiation-thermal modification of ferruginous bauxites during processing. Enrich Process 4:16-22 (in Russian)

Rostovtsev VI (2010) Theoretical foundations and practice of using electrochemical and radiation (accelerated electrons) effects in the processes of ore preparation and enrichment of mineral raw materials. Vestnik of the Chita State University, vol 8, pp 91-99. (in Russian)

Vakhrushev AV (2012) Crystal chemistry of bauxite minerals from the Vezhayu-Vorykvinskoe deposit. Structure, substance, history of the lithosphere of the Timan-Northern Ural segment. Geoprint, Syktyvkar, pp 32-34. (in Russian)

Vakhrushev AV, Lyutoev VP, Silaev VI (2012) Crystal-chemical features of ferrous minerals in bauxite at the Vezhayu-Vorykvinskoe deposit (Middle Timan). IG Komi Science Center UB RAS, pp 14-18. (in Russian)

Open Access This chapter is licensed under the terms of the Creative Commons Attribution 4.0 International License (http://creativecommons.org/licenses/by/4.0/), which permits use, sharing, adaptation, distribution and reproduction in any medium or format, as long as you give appropriate credit to the original author(s) and the source, provide a link to the Creative Commons license and indicate if changes were made.

The images or other third party material in this chapter are included in the chapter's Creative Commons license, unless indicated otherwise in a credit line to the material. If material is not included in the chapter's Creative Commons license and your intended use is not permitted by statutory regulation or exceeds the permitted use, you will need to obtain permission directly from the copyright holder.

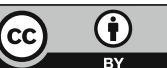

